\title{
Biztonságtudatosság a kibertérben - a 2020-as országos lakossági felmérés eredményei
}

\author{
Security awareness within the cyberspace - \\ results of the 2020 national survey among the population
}

\begin{tabular}{|c|c|c|c|}
\hline Palicz Tamás & \multicolumn{2}{|c|}{ Bonnyai Tünde } & Bencsik Balázs \\
\hline $\begin{array}{c}\text { Dr. igazgató-helyettes, } \\
\text { Semmelweis Egyetem, Egészségügyi } \\
\text { Menedzserképzö Központ } \\
\text { palicz.tamas@emk.semmelweis.hu }\end{array}$ & \multicolumn{2}{|c|}{$\begin{array}{l}\text { Dr. PhD, biztonsági szakértő, } \\
\text { MVM Services Zrt., } \\
\text { bonnyai.tunde@mvm.hu }\end{array}$} & $\begin{array}{c}\text { Dr. igazgató, } \\
\text { Szabályozott Tevékenységek } \\
\text { Felügyeleti Hatósága } \\
\text { balazs.bencsik@sztfh.hu }\end{array}$ \\
\hline Pintér Levente & \multicolumn{2}{|c|}{ Dombrádi Viktor } & Joó Tamás \\
\hline $\begin{array}{l}\text { Nemzetbiztonsági Szakszolgálat, } \\
\text { Nemzeti Kibervédelmi Intézet } \\
\text { levente.pinter@nki.gov.hu }\end{array}$ & \multicolumn{2}{|c|}{$\begin{array}{c}\text { PhD, adjunktus, } \\
\text { Semmelweis Egyetem, Egészségügyi } \\
\text { Menedzserképzö Központ } \\
\text { dombradi.viktor@emk.semmelweis.hu }\end{array}$} & $\begin{array}{c}\text { ügyvivő szakértő, } \\
\text { Semmelweis Egyetem, Egészségügyi } \\
\text { Menedzserképző Központ } \\
\text { joo.tamas@emk.semmelweis.hu }\end{array}$ \\
\hline \multicolumn{2}{|c|}{ Bor Olivér } & \multicolumn{2}{|c|}{ Hornyik Zsuzsanna } \\
\hline \multicolumn{2}{|c|}{$\begin{array}{c}\text { PR és kormányzati kapcsolatok vezető, } \\
\text { biztributor } \\
\text { obor@biztributor.hu }\end{array}$} & \multicolumn{2}{|c|}{$\begin{array}{l}\text { Dr. föszerkesztő-helyettes, } \\
\text { Belügyminisztérium, } \\
\text { Belügyi Szemle Szerkesztősége } \\
\text { zsuzsanna.hornyik@bm.gov.hu }\end{array}$} \\
\hline
\end{tabular}

\section{Absztrakt}

Cél: A tanulmány célja, hogy a Nemzeti Kibervédelmi Intézet által 2020ban országosan végzett lakossági kérdőív eredményein keresztül bemutassa, milyen jelentőséggel bír a kiberbiztonság a mai magyar társadalomban, miként befolyásolják azt szociodemográfiai tényezők és a biztonságtudatosság egyes elemei.

Módszertan: A dolgozat a Magyarországon végzett lakossági felmérés eredményeinek, a témában megjelent szakirodalomnak a feldolgozásával, elemzésével, összevetésével összegzi a vizsgálat célját képező biztonságtudatosságot, biztonsági szokásokat.

Megállapítások: A kitöltött kérdőívek feldolgozását követően többek között megállapítható, hogy a nemek eloszlása tekintetében inkább a férfiakra jellemző a legfrissebb IT-hírek olvasása, a jelszavak rendszeres frissítése, amely szokást a magasabb iskolai végzettség is jelentősen befolyásolt. Az idősebb generáció képviselői biztonsági okokból elsők között végeznek frissítéseket, veszik igénybe az ezirányú automatikus rendszereket, alkalmazásokat. A női felhasználók 
pedig - jelen felmérés tükrében - kevesebb olyan információt osztanak meg magukról, amelyek révén hamis profilt lehetne róluk készíteni.

Érték: A Nemzeti Kibervédelmi Intézet által kivitelezett felmérés kiértékelése, elemzése valódi érték, nélkülözhetetlen alapja a jövőbeni hasonló témájú felméréseknek és a nemzeti kiberbiztonsági stratégia fejlesztésének, illetve annak céljaihoz illeszkedő beavatkozások és akciótervek kidolgozásának.

Kulcsszavak: biztonságtudatosság, kiberbiztonság, lakossági felmérés, nemzeti stratégia, Európai Kiberhónap

\section{Abstract}

Aim: The goal of this study is to present the importance of cybersecurity in the present-day Hungarian society and to show how social demographic factors and certain aspects of security awareness influence this. This goal is achieved by presenting the results of the national survey conducted in 2020 by the National Cyber Security Center.

Methodology: This paper presents the findings of the Hungarian survey conducted among the population. By processing, analysing and comparing the results of the survey with the relevant literature, it presents a summary regarding security awareness and safety habits.

Findings: After evaluating the completed questionnaires, among many things, it can be stated that regarding gender distribution males are more likely to read the latest IT news and update their password regularly. These habits are also considerably more favourable for those having a higher education. Because of security reasons the members of the older generation are the ones who are among the first to do updates, and to utilize systems and applications that do this automatically. According to this survey females share less personal information about themselves which could be used to create a fake profile.

Value: The evaluation and analysis of the survey conducted by the National Cyber Security Center can be considered a true value, and is an essential basis for similar surveys in the future, for improving the national cybersecurity strategy, and for developing interventions and action plans for achieving the specified goals of this strategy.

Keywords: security awareness, cybersecurity, population survey, national strategy, European Cybersecurity Month (ECSM) 


\section{Bevezetés}

A 21. század egyik legnagyobb kihívása, hogy folyamatosan változó környezetünkre megtanuljunk reagálni - lehetőségeinkhez képest hatékonyan és eredményesen. A technológiai fejlődés révén be kell látnunk, hogy számtalan dinamikusan változó körülménnyel kell szembesülnünk életünk során, amelyek jelentős része a kibertérben, az online felületeken ér el bennünket, és sok esetben komoly hatást gyakorol a mindennapjainkra. A modern kor generációi számára eszközök, alkalmazások, platformok ezrei nyújtanak kényelmes, gyors és fejlödési lehetőségekben gazdag közeget, miközben óhatatlanul beszivárognak a magánéletünkbe, a privát szféránkba is. Ez a fajta kényelem veszélyeztető tényezők és kockázatok széles skáláját hozza magával, és a nem megfelelő reakciók esetén akár súlyos következményeket vonhat maga után. Rendkívül fontos, hogy a kibertér által hordozott veszélyek tekintetében az infokommunikációs eszközöket használók széles körében rendszeres, közérthető és célirányos figyelemfelkeltő tevékenységeket végezzünk annak érdekében, hogy a legfiatalabb generációtól a legtapasztaltabbon át, a legkevésbé érdeklődőig igyekezzünk rávilágítani az online tér előnyei mögött meghúzódó, lehetséges csapdákra is. Jelen tanulmánynyal azt a célt tüztük ki magunk elé, hogy egy hazai lakossági felmérésen keresztül érzékeltessük, miként befolyásolja az emberi tényező és a biztonságtudatosság a mai modern társadalmak működését. Biztonságtudatossággal kapcsolatos felmérések elemzésén keresztül láttatni szeretnénk, hogy a biztonságtudatosság szerte a világban ténylegesen befolyásolja a kiberbiztonságot.

A kiberbiztonság a modern információs társadalom, és az abban életre hívott szervezetek müködőképességének és rugalmas alkalmazkodóképességének (rezilienciájának) egyik kulcsterülete. A kibertér létezésének, fenntartásának, és müködésének sajátosságai miatt - az emberi kommunikációs csatornák markáns változásait, a diszlokációtól és időtől való függetlenséget, és különösen a COVID-19 pandémia következményeit figyelembe véve - fokozott figyelmet kell fordítani az úgynevezett ,átlagfelhasználó” szokásaira, magatartásformáira, összességében arra, hogy a rendelkezésre álló csatornákon és módszereken keresztül a személyi ellenálló képességet, a biztonságtudatos attitüdöt fokozatosan fejlesszük a társadalom lehető legszélesebb körében. A kibertér által hordozott számos fenyegetés, amely az elmúlt másfél évben, a pandémia alatt jelentősen megnőtt (Szabó, 2021; Palicz, Bencsik \& Szócska, 2021), egyértelműen alátámasztja, hogy a felhasználói magatartás, azon belül is a biztonságtudatosság a kibertér biztonságos használatának egyik alapja.

A biztonságtudatosság növelése - elsősorban ismeretterjesztés, képzések és készségfejlesztés révén - minden esetben javítja az információs rendszerek 
biztonságát, nemcsak a munkahelyen, hanem az otthoni környezetben is. Ezen kampányok, tevékenységek és módszertanok tervezése kapcsán szükséges figyelembe venni, hogy a megszólítani kívánt egyén vagy csoport milyen ismeretekkel és attitüdökkel rendelkezik ezen a területen (Oroszi, 2020), és törekedni kell arra, hogy a leginkább személyre szabott tartalommal valósítsuk meg a tudatosítási programunkat. A szakirodalmakban fellelhető adatok alapján kijelenthetjük, hogy a kiberbiztonsággal kapcsolatos nem megfelelő attitüd és tudás hiánya jelentős mértékben hozzájárulhat a szervezetnél - és a magánéletben jellemző biztonsági szint csökkenéséhez (Sasse \& Flechais, 2005; Nyikes, 2019).

Mindezekre tekintettel Magyarországon is egyre nagyobb hangsúlyt kapnak a kiberbiztonsági tudatosítással kapcsolatos kérdések. Ezt mutatja az is, hogy Magyarország Kormánya 2018 végén a 1838/2018. (XII. 28.) Korm. határozattal elfogadta Magyarország hálózati és információs rendszerek biztonságára vonatkozó stratégiáját, amelyben egy úgynevezett „irányítási keretrendszert” hívott életre. Az ennek jegyében meghatározott stratégiai szintü feladatokat a digitális környezet iránti bizalom erősítése, a digitális infrastruktúra védelme, illetve a gazdasági szereplők támogatása köré csoportosíthatjuk, amelyeken alapulva külön intézkedési terv rögzíti a részletes tevékenységeket és felelösségi köröket. Ezek között találhatunk olyan törekvéseket, mint olyan fórumok kialakításának szükségessége, amelyek révén lehetőség nyílik a társadalmi párbeszédre és a széles körü tájékoztatásra, vagy annak biztosítása, hogy a lakosság és a gazdasági szereplők ismerjék azokat a forrásokat (helyek, szervezetek stb.), ahol hiteles információhoz juthatnak, illetve támogatást kaphatnak abban, hova fordulhatnak további segítségért. Mindehhez nélkülözhetetlen, hogy az illetékes szervezeteknél rendelkezésre álljanak megalapozott, követéses adatok a lakosság és a gazdasági szereplők tájékozottságáról, tudatosságáról, felkészültségéről, fenyegetettségi helyzetéről. Ennek biztosítására az intézkedési terv a Nemzetbiztonsági Szakszolgálat Nemzeti Kibervédelmi Intézete számára elöírta, hogy minden évben szükséges a lakosság és a kis- és középvállalati szektor biztonságtudatosságának felmérése. Ennek első vizsgálata 2020 októberében, az Európai Kiberbiztonsági Hónap keretében történt meg (URL1).

A felmérés célcsoportjainak kiválasztása nem volt specifikus, általános értelemben célozta a lakosságot - kortól, nemtől, lakóhelytől és munkavégzéstől függetlenül -, illetve gazdasági társaságokat szólított meg. Jelen tanulmány ennek a felmérésnek a lakossági eredményeit mutatja be, mint egy olyan kiterjedt felmérést, amely a teljes lakosságot vette górcső alá, illetve tervezetten, a kormány elöírásának megfelelően, évente ismétlésre kerül. Ugyanakkor fontos hangsúlyozni, hogy nem ez az első felmérés Magyarországon, amely az adott kérdéskörrel foglalkozik, és több hazai publikáció (Nyikes, 2017a, 2017b) és 
egy PhD-értekezés (Nyikes, 2019) is elemezte a lakosok attitüdjét és szokásait a kiberbiztonsággal kapcsolatosan.

A mostani tanulmány fő célja, hogy a 2020-ban, a Nemzetbiztonsági Szakszolgálat Nemzeti Kibervédelmi Intézet (továbbiakban: Intézet) irányításával végzett lakossági felmérés eredményeit összefoglalja, azok felhasználásával bemutassa, hogy a mai magyar társadalomban milyen jelentőséget tulajdonítanak a kiberbiztonsági kérdéseknek felhasználói szinten. A hazai és nemzetközi irodalom feldolgozásán keresztül azt is vizsgáljuk és bemutatjuk, hogy a jelenleg rendelkezésre álló kutatások eredményei alapján a kibertérben meglevő biztonságtudatosság milyen szerepet tölt be a modern társadalmakban, miként befolyásolják annak összetevőit a szociodemográfiai tényezők. A felmérés során a célcsoportokat a stratégiai dokumentumokban meghatározott feladatok definiálták (általános lakossági és gazdasági társaságok körében végzendő felmérés), azonban az így nyert információk hasznosak lehetnek a stratégia további fejlesztése és az annak alapján meghatározásra kerülő kezdeményezések, intézkedések tervezésénél és végrehajtásánál egyaránt.

\section{Módszer}

A lakossági felmérés során alkalmazott módszerek tekintetében ismertetésre kerül, hogy milyen viszonyítási alap mentén történt fejlesztés szerint készültek a kérdőívek, miként került meghatározásra a célcsoport, milyen időszakban zajlott, mely kommunikációs csatornákon keresztül és milyen módon a felmérés. A feladat végrehajtásának tervezésekor figyelembe kellett vennünk, hogy országos szintü adatgyüjtést kell végezni, ezért az információgyűjjtést kvantitatív módszertani megközelítéssel, a célközönség számára könnyen hozzáférhető online kérdőíves felmérés keretében valósítottuk meg. Két online kérdőív készült - külön a lakosság és külön a közigazgatási szervek, valamint gazdasági társaságok számára - az Európai Bizottság által müködtetett EUSurvey (URL2) webes platform felhasználásával, amelyet az Európai Uniós Kiberbiztonsági Ügynökség (European Union Agency for Cybersecurity - ENISA) is alkalmaz. A kérdőívek három kommunikációs csatornán kerültek publikálásra: az Intézet weboldalán, az Intézet Facebook-oldalán - amellyel kapcsolatban a kérdések minél szélesebb célközönséghez történő eljuttatásához hirdetési rendszert is igénybe vettünk -, valamint a gazdasági szereplöknek és a közigazgatási szférában dolgozóknak szóló kérdőív elektronikus úton, az Intézet ügyfélkörébe tartozó szervezetek és partnerintézmények számára pedig külön került megküldésre. 
Az online kérdőívek 2020. október 28. és 2020. november 30. között voltak elérhetők. Összesen 1792 kitöltött kérdőív került benyújtásra, amelyek közül a lakossági szereplők kérdéseire összesen 1104 válasz érkezett.

A kérdések kialakításánál célunk a legalapvetőbb IT-biztonsági ismeretek és szokások feltérképezése volt. A lakossági és a gazdasági társaságok tekintetében egyaránt 20-20 kérdést készítettünk. Természetesen a témakör mélysége jóval hosszabb kérdőív elkészítését is lehetővé tette volna, azonban szem előtt tartottuk, hogy a hosszú kérdőívek esetében a válaszadók motivációja egy idő után csökken, és nagyobb valószínüséggel születnek sztereotipikus válaszok (Herzog \& Bachman, 1981).

A stratégiai intézkedési terv által elöírt négy fö vizsgálati kategória (tájékozottság, tudatosság, felkészültség, fenyegetettségi helyzet) tekintetében az alábbi szempontokat vettük figyelembe.

- Tájékozottság. Ebben a témakörben arra helyeztük a hangsúlyt, hogy a lakossági szereplők mennyire követik az IT-biztonsági híreket, informálódnak-e. Arra is kerestük a választ, hogy vajon mennyien vannak tisztában azzal, hogy a Nemzeti Kibervédelmi Intézethez segítségért fordulhatnak, amennyiben adatbiztonsági incidensben érintettek, valamint, hogy menynyire tájékozottak a különböző online szolgáltatások által végzett adatgyüjtéssel kapcsolatban.

- Tudatosság. A kategóriában az egyének által alkalmazható legalapvetőbb IT-biztonsági védelmi lépések (vírusirtó szoftver használata, biztonsági frissítések telepítése) alkalmazásáról tettünk fel kérdéseket. Az adatvédelmi tudatosság tekintetében arra voltunk kíváncsiak, hogy a mindennapokból jól ismert weboldal sütik és az okoseszközök adatvédelmi beállításai, valamint az online szolgáltatások kiválasztása során a lakossági szereplők mennyire járnak el tudatosan.

- Felkészültség. Az alapszintü IT-biztonsági jó gyakorlatok vizsgálatakor jelszóalkalmazási, és az e-mail csatolmányok kezelésére vonatkozó jó gyakorlatokat vizsgáltuk, mivel ezek - bár alapszintü IT-biztonsági ismeretek - kiemelt jelentőséggel bírnak a kibertámadások elleni védekezésben.

- Fenyegetettség. A kibertámadásoknak való kitettséget befolyásoló olyan tényezőket vizsgáltunk, mint például a lakossági szereplők mennyire tartják elképzelhetőnek azt, hogy rosszindulatú felek a közösségi média profiljukat lemásolva megszemélyesítik őket.

A beérkezett adatok adattisztítási folyamata során a születési évet átalakítottuk életkorra (életkor $=2020$-évszám), majd ezt követően az életkorokat korcsoportokba és generációkba soroltuk (Baby-boom, X, Y, Z generációk). Korrigálható 
hibák esetén az értékeket átírtuk, viszont az értelmezhetetlen adatokat tartalmazó rekordokat töröltük (például 0 életév). Feltehetően ezek a hibák a kitöltés során kerültek az adatbázisba.

Az összehasonlító statisztikai elemzések kivitelezésére a demográfiai adatokat és a válaszlehetőségeket dichotomizáltuk, vagyis két csoportba soroltuk (lásd 2-10. táblázatokat az Eredmények fejezetben). A csoportok kialakításánál figyelembe vettük a válaszadók és a válaszok megoszlását, valamint törekedtünk arra, hogy szakmailag is informatívak legyenek a következtetések. Ennek keretén belül például az általános iskolai és középiskolai végzettséggel rendelkezők egy csoportba kerültek.

Az eredeti lakossági kérdőív feldolgozásakor nem elemeztük az összes kérdést, mivel bizonyos kérdések válaszai ugyan érdekesek, viszont szakmai szempontból nem tekinthetők relevánsnak. Ilyen kérdés volt például, hogy „Az alábbi lehetöségek közül Ön melyiket preferálja okoseszközök képernyözárának feloldásához?". Ebből adódóan az eredeti húsz kérdésből kilencet vizsgáltunk meg összehasonlító statisztika segítségével.

A statisztikai elemzés keretén belül elsőnek leíró statisztikával megnéztük a demográfiai adatok elemszámát és százalékos megoszlását, majd szisztematikusan megnéztük Khí-négyzet próba segítségével, hogy a dichotomizált demográfiai adatok milyen kapcsolatban állnak a dichotomizált kérdések válaszaival. Végezetül mátrix elemzéssel azt is megnéztük, hogy a különböző kérdések között milyen lehetséges kapcsolat található. A mátrix elemzés során is Khí-négyzet próbát alkalmaztunk. A szignifikancia szintjét $\mathrm{P}<0,05$ értékben határoztuk meg. Az összes statisztikai elemzéshez SPSS 27 programot használtunk (IBM Corp. Released 2020. IBM SPSS Statistics for Windows, Version 27.0. Armonk, NY: IBM Corp).

\section{Eredmények}

Összesen 1104 kitöltő válaszait dolgoztuk fel a vizsgálatunk során (1. számú táblázat). A kitöltők több mint háromnegyede férfi (77,2\%), egyötöde nő $(21,8 \%)$ volt, míg 11 -en nem adták meg a nemüket (1,0\%). A legtöbben a 35-44 (30,1\%), 45-54 (18,1\%) és 25-34 (15,8\%) korcsoportokban voltak. A kitöltők több mint felének $(58,7 \%)$ föiskolai vagy egyetemi diplomája volt. A lakóhelyet tekintve a kitöltők 35,5\%-a Budapestről, 24,1\%-a valamelyik megyei jogú városból, míg 40,1\%-a egyéb településről származik. Ezen adatok alapján kijelenthető, hogy a felmérés nem volt reprezentatív az általános lakosságra vonatkozóan, így a felmérésböl származó következtetéseket csak óvatosan szabad általánosítani. 


\section{1. számú táblázat: Válaszadók demográfiai adatai}

\begin{tabular}{|c|c|c|}
\hline Nem & $\mathbf{N}$ & $\%$ \\
\hline Férfi & 852 & 77,2 \\
\hline Nő & 241 & 21,8 \\
\hline Nincs adat & 11 & 1,0 \\
\hline Kor & $\mathbf{N}$ & $\%$ \\
\hline$<18$ & 46 & 4,2 \\
\hline $18-24$ & 89 & 8,1 \\
\hline $25-34$ & 174 & 15,8 \\
\hline $35-44$ & 332 & 30,1 \\
\hline $45-54$ & 200 & 18,1 \\
\hline $55-64$ & 121 & 11,0 \\
\hline $65-74$ & 121 & 11,0 \\
\hline 75 és idősebb & 20 & 1,8 \\
\hline Nincs adat & 1 & 0,1 \\
\hline Iskolázottság & $\mathbf{N}$ & $\%$ \\
\hline Általános iskola & 65 & 5,9 \\
\hline Középiskola & 391 & 35,4 \\
\hline Főiskola/egyetem & 648 & 58,7 \\
\hline Lakóhely & $\mathbf{N}$ & $\%$ \\
\hline Budapest & 392 & 35,5 \\
\hline Megyei jogú város & 266 & 24,1 \\
\hline Egyéb & 446 & 40,4 \\
\hline Eszközök (többválasztós kérdés) & $\mathbf{N}$ & $\%$ \\
\hline Számítógép & 755 & 68,4 \\
\hline Laptop & 1104 & 100 \\
\hline Tablet & 558 & 50,5 \\
\hline Okostelefon & 1061 & 96,1 \\
\hline Okosóra & 280 & 25,4 \\
\hline Okoskarkötő & 169 & 15,3 \\
\hline Okos háztartási eszköz & 212 & 19,2 \\
\hline Eszközök használata naponta (óra) & $\mathbf{N}$ & $\%$ \\
\hline 0-3 óra & 164 & 14,9 \\
\hline 3-6 óra & 325 & 29,4 \\
\hline 6-9 óra & 294 & 26,6 \\
\hline 9 vagy több óra & 321 & 29,1 \\
\hline
\end{tabular}

Forrás: A szerzők saját szerkesztése. 
Mindenkinek volt laptopja (100\%) és majdnem mindenki rendelkezett okostelefonnal (96,1\%). A válaszadók több mint felének volt számítógépe $(68,4 \%)$ és tabletje (50,5\%). Az elektronikus eszközök használatára a kitöltők többsége napi 3-6 órát fordít (29,4\%), viszont nem sokkal vannak kevesebben azok, akik naponta 9 vagy több órát használják ezeket az eszközöket $(29,1 \%)$.

2. számú táblázat: Válaszadók olvasási gyakorisága IT-biztonság témájában

\begin{tabular}{|c|c|c|c|c|c|}
\hline \multirow{2}{*}{ Változók } & \multirow{2}{*}{ Kategóriák } & \multicolumn{2}{|c|}{$\begin{array}{c}\text { Ön milyen gyakorisággal } \\
\text { olvas IT-biztonsággal } \\
\text { kapcsolatos híreket? }\end{array}$} & \multirow{2}{*}{$\begin{array}{l}\text { Összes } \\
\text { válasz }\end{array}$} & \multirow{2}{*}{ P-érték } \\
\hline & & $\begin{array}{c}\text { Nem } \\
\text { rendszeresen }\end{array}$ & Rendszeresen & & \\
\hline \multirow{4}{*}{ Nem } & \multirow{2}{*}{ férfi } & 369 & 483 & 852 & \multirow{4}{*}{$<0,001$} \\
\hline & & $43,3 \%$ & $56,7 \%$ & $100 \%$ & \\
\hline & \multirow{2}{*}{ nő } & 172 & 69 & 241 & \\
\hline & & $71,4 \%$ & $28,6 \%$ & $100 \%$ & \\
\hline \multirow{4}{*}{$\begin{array}{l}\text { Legmagasabb } \\
\text { iskolai } \\
\text { végzettség }\end{array}$} & \multirow{2}{*}{ általános vagy középiskola } & 244 & 212 & 456 & \multirow{4}{*}{$\mathbf{0 , 0 3 5}$} \\
\hline & & $53,5 \%$ & $46,5 \%$ & $100 \%$ & \\
\hline & \multirow{2}{*}{ föiskola vagy egyetem } & 305 & 343 & 648 & \\
\hline & & $47,1 \%$ & $52,9 \%$ & $100 \%$ & \\
\hline \multirow{4}{*}{ Generáció } & \multirow{2}{*}{$\mathrm{X}$ vagy Baby-boom } & 358 & 329 & 687 & \multirow{4}{*}{0,046} \\
\hline & & $52,1 \%$ & $47,9 \%$ & $100 \%$ & \\
\hline & \multirow{2}{*}{ Y vagy $Z$ generáció } & 191 & 225 & 416 & \\
\hline & & $45,9 \%$ & $54,1 \%$ & $100 \%$ & \\
\hline \multirow{4}{*}{$\begin{array}{l}\text { Napi szinten } \\
\text { több, mint hat } \\
\text { órát használja } \\
\text { az eszközeit }\end{array}$} & \multirow{2}{*}{$0-6$ óra } & 304 & 185 & 489 & \multirow{4}{*}{$<0,001$} \\
\hline & & $62,2 \%$ & $37,8 \%$ & $100 \%$ & \\
\hline & \multirow{2}{*}{$6 \leq$ óra } & 245 & 370 & 615 & \\
\hline & & $39,8 \%$ & $60,2 \%$ & $100 \%$ & \\
\hline \multirow{4}{*}{ Lakóhely } & \multirow{2}{*}{$\begin{array}{l}\text { Budapest vagy megyei } \\
\text { jogú város }\end{array}$} & 295 & 363 & 658 & \multirow{4}{*}{$<0,001$} \\
\hline & & $44,8 \%$ & $55,2 \%$ & $100 \%$ & \\
\hline & \multirow{2}{*}{ egyéb } & 254 & 192 & 446 & \\
\hline & & $57,0 \%$ & $43,0 \%$ & $100 \%$ & \\
\hline \multirow{4}{*}{$\begin{array}{l}\text { Több, mint } \\
\text { három } \\
\text { eszközzel } \\
\text { rendelkezik }\end{array}$} & \multirow{2}{*}{ igen } & 96 & 170 & 266 & \multirow{4}{*}{$<0,001$} \\
\hline & & $36,1 \%$ & $63,9 \%$ & $100 \%$ & \\
\hline & \multirow{2}{*}{ nem } & 453 & 385 & 838 & \\
\hline & & $54,1 \%$ & $45,9 \%$ & $100 \%$ & \\
\hline
\end{tabular}

Forrás: A szerzők saját szerkesztése. 
3. számú táblázat: Válaszadók szokása weboldal-regisztráció során

\begin{tabular}{|c|c|c|c|c|c|}
\hline \multirow[t]{2}{*}{ Változók } & \multirow[t]{2}{*}{ Kategóriák } & \multicolumn{2}{|c|}{$\begin{array}{l}\text { Regisztráció során Ön el szokta } \\
\text { olvasni a weboldalak adatvédelmi } \\
\text { szabályzatait? }\end{array}$} & \multirow[t]{2}{*}{$\begin{array}{l}\text { Összes } \\
\text { válasz }\end{array}$} & \multirow[t]{2}{*}{ P-érték } \\
\hline & & Igen & Nem & & \\
\hline \multirow{4}{*}{ Nem } & \multirow{2}{*}{ férfi } & 618 & 234 & 852 & \multirow{4}{*}{$\mathbf{0 , 1 0 7}$} \\
\hline & & $72,5 \%$ & $27,5 \%$ & $100 \%$ & \\
\hline & \multirow{2}{*}{ nő } & 162 & 79 & 241 & \\
\hline & & $67,2 \%$ & $32,8 \%$ & $100 \%$ & \\
\hline \multirow{4}{*}{$\begin{array}{l}\text { Legmagasabb } \\
\text { iskolai } \\
\text { végzettség }\end{array}$} & \multirow{2}{*}{$\begin{array}{l}\text { általános vagy } \\
\text { középiskola }\end{array}$} & 296 & 160 & 456 & \multirow{4}{*}{$\mathbf{0 , 2 3 7}$} \\
\hline & & $64,9 \%$ & $35,1 \%$ & $100 \%$ & \\
\hline & \multirow{2}{*}{$\begin{array}{l}\text { föiskola vagy } \\
\text { egyetem }\end{array}$} & 398 & 250 & 648 & \\
\hline & & $61,4 \%$ & $38,6 \%$ & $100 \%$ & \\
\hline \multirow{4}{*}{ Generáció } & \multirow{2}{*}{$\begin{array}{l}\text { X vagy } \\
\text { Baby-boom }\end{array}$} & 443 & 244 & 687 & \multirow{4}{*}{0,144} \\
\hline & & $64,5 \%$ & $35,5 \%$ & $100 \%$ & \\
\hline & \multirow{2}{*}{$\begin{array}{l}\text { Y vagy } Z \\
\text { generáció }\end{array}$} & 250 & 166 & 416 & \\
\hline & & $60,1 \%$ & $39,9 \%$ & $100 \%$ & \\
\hline \multirow{4}{*}{$\begin{array}{l}\text { Napi szinten } \\
\text { több, mint hat } \\
\text { órát használja } \\
\text { az eszközeit }\end{array}$} & \multirow{2}{*}{ 0-6 óra } & 319 & 170 & 489 & \multirow{4}{*}{0,146} \\
\hline & & $65,2 \%$ & $34,8 \%$ & $100 \%$ & \\
\hline & \multirow{2}{*}{$6 \leq$ óra } & 375 & 240 & 615 & \\
\hline & & $61,0 \%$ & $39,0 \%$ & $100 \%$ & \\
\hline \multirow{4}{*}{ Lakóhely } & \multirow{2}{*}{$\begin{array}{l}\text { Budapest vagy } \\
\text { megyei jogú város }\end{array}$} & 401 & 257 & 658 & \multirow{4}{*}{0,109} \\
\hline & & $60,9 \%$ & $39,1 \%$ & $100 \%$ & \\
\hline & \multirow{2}{*}{ egyéb } & 293 & 153 & 446 & \\
\hline & & $65,7 \%$ & $34,3 \%$ & $100 \%$ & \\
\hline \multirow{4}{*}{$\begin{array}{l}\text { Több, mint } \\
\text { három } \\
\text { eszközzel } \\
\text { rendelkezik }\end{array}$} & \multirow{2}{*}{ igen } & 178 & 88 & 266 & \multirow{4}{*}{0,116} \\
\hline & & $66,9 \%$ & $33,1 \%$ & $100 \%$ & \\
\hline & \multirow{2}{*}{ nem } & 516 & 322 & 838 & \\
\hline & & $61,6 \%$ & $38,4 \%$ & $100 \%$ & \\
\hline
\end{tabular}

Forrás: A szerzők saját szerkesztése.

Az IT-biztonsággal kapcsolatos híreket (2. számú táblázat) szignifikánsan gyakrabban olvassák a férfiak $(\mathrm{P}<0,001)$, fóiskolai vagy egyetemi diplomával rendelkezők ( $\mathrm{P}=0,035)$, a fiatalabb generációk ( $\mathrm{Z}$ vagy $\mathrm{Y}$ generációk; $\mathrm{P}=0,046)$, akik naponta hat vagy több óránál többet használják az elektronikus eszközeiket $(\mathrm{P}<0,001)$, a budapesti vagy megyei jogú város lakosai $(\mathrm{P}<0,001)$, és azok, akik több mint három eszközzel rendelkeznek $(\mathrm{P}<0,001)$.

Ezzel szemben sehol sem találtunk szignifikáns eltérést annak tekintetében, hogy a regisztráció során elolvassák-e a weboldalak adatvédelmi szabályzatát (3. számú táblázat). 
Az idősebb generációra (Baby-boom vagy X generációk) inkább jellemző, hogy amint kijönnek a biztonsági eszközök frissítései, az elöre beállított automatikus frissítés következtében azonnal elvégzik a frissítést $(\mathrm{P}<0,001)$ (4. számú táblázat). Ugyanez az állítás jellemző azokra is, akiknek három vagy több fajta elektronikus eszközük van $(\mathrm{P}=0,006)$.

4. számú táblázat: Válaszadók szokása a biztonsági frissitést illetően

\begin{tabular}{|c|c|c|c|c|c|}
\hline \multirow[b]{2}{*}{ Változók } & \multirow[b]{2}{*}{ Kategóriák } & \multicolumn{2}{|c|}{$\begin{array}{l}\text { Ön milyen gyakorisággal végez } \\
\text { biztonsági frissítést eszközein? }\end{array}$} & \multirow[b]{2}{*}{$\begin{array}{l}\text { Összes } \\
\text { válasz }\end{array}$} & \multirow[b]{2}{*}{ P-érték } \\
\hline & & $\begin{array}{l}\text { Amint kijönnek a fris- } \\
\text { sítések, mert be van } \\
\text { állítva az automatikus } \\
\text { frissítés }\end{array}$ & Egyéb & & \\
\hline \multirow{4}{*}{ Nem } & \multirow{2}{*}{ férfi } & 618 & 234 & 852 & \multirow{4}{*}{0,107} \\
\hline & & $72,5 \%$ & $27,5 \%$ & $100 \%$ & \\
\hline & \multirow{2}{*}{ nő } & 162 & 79 & 241 & \\
\hline & & $67,2 \%$ & $32,8 \%$ & $100 \%$ & \\
\hline \multirow{4}{*}{$\begin{array}{l}\text { Legmagasabb } \\
\text { iskolai } \\
\text { végzettség }\end{array}$} & \multirow{2}{*}{$\begin{array}{l}\text { általános vagy } \\
\text { középiskola }\end{array}$} & 318 & 138 & 456 & \multirow{4}{*}{0,369} \\
\hline & & $69,7 \%$ & $30,3 \%$ & $100 \%$ & \\
\hline & \multirow{2}{*}{$\begin{array}{l}\text { föiskola vagy } \\
\text { egyetem }\end{array}$} & 468 & 180 & 648 & \\
\hline & & $72,2 \%$ & $27,8 \%$ & $100 \%$ & \\
\hline \multirow{4}{*}{ Generáció } & \multirow{2}{*}{$\begin{array}{l}\text { X vagy Baby- } \\
\text { boom }\end{array}$} & 517 & 170 & 687 & \multirow{4}{*}{$<0,001$} \\
\hline & & $75,3 \%$ & $24,7 \%$ & $100 \%$ & \\
\hline & \multirow{2}{*}{$\begin{array}{l}\text { Y vagy } Z \\
\text { generáció }\end{array}$} & 268 & 148 & 416 & \\
\hline & & $64,4 \%$ & $35,6 \%$ & $100 \%$ & \\
\hline \multirow{4}{*}{$\begin{array}{l}\text { Napi szinten } \\
\text { több, mint hat } \\
\text { órát használja } \\
\text { az eszközeit }\end{array}$} & \multirow{2}{*}{ 0-6 óra } & 350 & 139 & 489 & \multirow{4}{*}{0,804} \\
\hline & & $71,6 \%$ & $28,4 \%$ & $100 \%$ & \\
\hline & \multirow{2}{*}{$6 \leq$ óra } & 436 & 179 & 615 & \\
\hline & & $70,9 \%$ & $29,1 \%$ & $100 \%$ & \\
\hline \multirow{4}{*}{ Lakóhely } & \multirow{2}{*}{$\begin{array}{l}\text { Budapest } \\
\text { vagy megyei } \\
\text { jogú város }\end{array}$} & 479 & 179 & 658 & \multirow{4}{*}{0,154} \\
\hline & & $72,8 \%$ & $27,2 \%$ & $100 \%$ & \\
\hline & \multirow{2}{*}{ egyéb } & 307 & 139 & 446 & \\
\hline & & $68,8 \%$ & $31,2 \%$ & $100 \%$ & \\
\hline \multirow{4}{*}{$\begin{array}{l}\text { Több, mint } \\
\text { három } \\
\text { eszközzel } \\
\text { rendelkezik }\end{array}$} & \multirow{2}{*}{ igen } & 207 & 59 & 266 & \multirow{4}{*}{0,006} \\
\hline & & $77,8 \%$ & $22,2 \%$ & $100 \%$ & \\
\hline & \multirow{2}{*}{ nem } & 579 & 259 & 838 & \\
\hline & & $69,1 \%$ & $30,9 \%$ & $100 \%$ & \\
\hline
\end{tabular}

Forrás: A szerzők saját szerkesztése. 
A válaszadók $90,8 \%$ válaszolta, hogy van vírusirtó szoftver a számítógépén vagy a laptopján (5. számú táblázat). Ez az arány szignifikánsan magasabb a nőknél $(\mathrm{P}=0,014)$, a főiskolai vagy egyetemi diplomával rendelkezőknél $(\mathrm{P}=0,008)$ és az idősebb generációnál (Baby-boom vagy $\mathrm{X}$ generációk) $(\mathrm{P}<0,001)$.

A férfiakra jellemzőbb, hogy inkább több jelszót használnak különböző online felületek használatakor $(\mathrm{P}<0,001)$ (6. számú táblázat), továbbá ez jellemzőbb még a föiskolai vagy egyetemi végzettséggel rendelkezőkre is $(\mathrm{P}<0,001)$.

5. számú táblázat: Válaszadók vírusirtó szoftver használata

\begin{tabular}{|c|c|c|c|c|c|}
\hline \multirow{2}{*}{ Változók } & \multirow{2}{*}{ Kategóriák } & \multicolumn{2}{|c|}{$\begin{array}{c}\text { Használ-e a számítógépén/laptopján } \\
\text { vírusirtó szoftvert? }\end{array}$} & \multirow{2}{*}{$\begin{array}{l}\text { Összes } \\
\text { válasz }\end{array}$} & \multirow{2}{*}{ P-érték } \\
\hline & & Igen & Nem & & \\
\hline \multirow{4}{*}{ Nem } & \multirow{2}{*}{ férfi } & 755 & 85 & 840 & \multirow{4}{*}{0,014} \\
\hline & & $89,9 \%$ & $10,1 \%$ & $100 \%$ & \\
\hline & \multirow{2}{*}{ nő } & 216 & 11 & 227 & \\
\hline & & $95,2 \%$ & $4,8 \%$ & $100 \%$ & \\
\hline \multirow{4}{*}{$\begin{array}{l}\text { Legmagasabb } \\
\text { iskolai } \\
\text { végzettség }\end{array}$} & \multirow{2}{*}{$\begin{array}{l}\text { általános vagy } \\
\text { középiskola }\end{array}$} & 389 & 53 & 442 & \multirow{4}{*}{0,008} \\
\hline & & $88,0 \%$ & $12,0 \%$ & $100 \%$ & \\
\hline & \multirow{2}{*}{$\begin{array}{l}\text { föiskola vagy } \\
\text { egyetem }\end{array}$} & 590 & 46 & 636 & \\
\hline & & $92,8 \%$ & $7,2 \%$ & $100 \%$ & \\
\hline \multirow{4}{*}{ Generáció } & \multirow{2}{*}{$\begin{array}{l}\text { X vagy } \\
\text { Baby-boom }\end{array}$} & 632 & 44 & 676 & \multirow{4}{*}{$<0,001$} \\
\hline & & $93,5 \%$ & $6,5 \%$ & $100 \%$ & \\
\hline & \multirow{2}{*}{$\begin{array}{l}\text { Y vagy } \\
\text { Z generáció }\end{array}$} & 346 & 55 & 401 & \\
\hline & & $86,3 \%$ & $13,7 \%$ & $100 \%$ & \\
\hline \multirow{4}{*}{$\begin{array}{l}\text { Napi szinten } \\
\text { több, mint hat } \\
\text { órát használja } \\
\text { az eszközeit }\end{array}$} & \multirow{2}{*}{ 0-6 óra } & 440 & 41 & 481 & \multirow{4}{*}{0,501} \\
\hline & & $91,5 \%$ & $8,5 \%$ & $100 \%$ & \\
\hline & \multirow{2}{*}{$6 \leq$ óra } & 539 & 58 & 597 & \\
\hline & & $90,3 \%$ & $9,7 \%$ & $100 \%$ & \\
\hline \multirow{4}{*}{ Lakóhely } & \multirow{2}{*}{$\begin{array}{l}\text { Budapest vagy } \\
\text { megyei jogú város }\end{array}$} & 595 & 52 & 647 & \multirow{4}{*}{0,110} \\
\hline & & $92,0 \%$ & $8,0 \%$ & $100 \%$ & \\
\hline & \multirow{2}{*}{ egyéb } & 384 & 47 & 431 & \\
\hline & & $89,1 \%$ & $10,9 \%$ & $100 \%$ & \\
\hline \multirow{4}{*}{$\begin{array}{l}\text { Több, mint } \\
\text { három } \\
\text { eszközzel } \\
\text { rendelkezik }\end{array}$} & \multirow{2}{*}{ igen } & 239 & 20 & 259 & \multirow{4}{*}{0,350} \\
\hline & & $92,3 \%$ & $7,7 \%$ & $100 \%$ & \\
\hline & \multirow{2}{*}{ nem } & 740 & 79 & 819 & \\
\hline & & $90,4 \%$ & $9,6 \%$ & $100 \%$ & \\
\hline
\end{tabular}

Forrás: A szerzők saját szerkesztése. 
6. számú táblázat: Válaszadók jelszóhasználati szokása

\begin{tabular}{|c|c|c|c|c|c|}
\hline \multirow[b]{2}{*}{ Változók } & \multirow[b]{2}{*}{ Kategóriák } & \multicolumn{2}{|c|}{$\begin{array}{c}\text { A különböző online felületeken eltérö } \\
\text { jelszavakat használ? }\end{array}$} & \multirow[b]{2}{*}{$\begin{array}{l}\text { Összes } \\
\text { válasz }\end{array}$} & \multirow[b]{2}{*}{ P-érték } \\
\hline & & $\begin{array}{c}\text { Eltérō jelszavakat } \\
\text { használok }\end{array}$ & $\begin{array}{c}\text { Törekszem a mi- } \\
\text { nél kevesebb } \\
\text { jelszó megjegy- } \\
\text { zésére }\end{array}$ & & \\
\hline \multirow{4}{*}{ Nem } & \multirow{2}{*}{ férfi } & 625 & 199 & 824 & \multirow{4}{*}{$<0,001$} \\
\hline & & $75,8 \%$ & $24,2 \%$ & $100 \%$ & \\
\hline & \multirow{2}{*}{ nő } & 141 & 80 & 221 & \\
\hline & & $63,8 \%$ & $36,2 \%$ & $100 \%$ & \\
\hline \multirow{4}{*}{$\begin{array}{l}\text { Legmagasabb } \\
\text { iskolai } \\
\text { végzettség }\end{array}$} & \multirow{2}{*}{$\begin{array}{l}\text { általános vagy } \\
\text { középiskola }\end{array}$} & 288 & 144 & 432 & \multirow{4}{*}{$<0,001$} \\
\hline & & $66,7 \%$ & $33,3 \%$ & $100 \%$ & \\
\hline & \multirow{2}{*}{$\begin{array}{l}\text { föiskola vagy } \\
\text { egyetem }\end{array}$} & 487 & 137 & 624 & \\
\hline & & $78,0 \%$ & $22,0 \%$ & $100 \%$ & \\
\hline \multirow{4}{*}{ Generáció } & \multirow{2}{*}{$\begin{array}{l}\text { X vagy Baby- } \\
\text { boom }\end{array}$} & 475 & 190 & 665 & \multirow{4}{*}{0,054} \\
\hline & & $71,4 \%$ & $28,6 \%$ & $100 \%$ & \\
\hline & \multirow{2}{*}{$\begin{array}{l}\text { Y vagy } \mathrm{Z} \text { gene- } \\
\text { ráció }\end{array}$} & 300 & 90 & 390 & \\
\hline & & $76,9 \%$ & $23,1 \%$ & $100 \%$ & \\
\hline \multirow{4}{*}{$\begin{array}{l}\text { Napi szinten } \\
\text { több, mint hat } \\
\text { órát használja } \\
\text { az eszközeit }\end{array}$} & \multirow{2}{*}{$0-6$ óra } & 329 & 137 & 466 & \multirow{4}{*}{0,068} \\
\hline & & $70,6 \%$ & $29,4 \%$ & $100 \%$ & \\
\hline & \multirow{2}{*}{$6 \leq$ óra } & 446 & 144 & 590 & \\
\hline & & $75,6 \%$ & $24,4 \%$ & $100 \%$ & \\
\hline \multirow{4}{*}{ Lakóhely } & \multirow{2}{*}{$\begin{array}{l}\text { Budapest vagy } \\
\text { megyei jogú város }\end{array}$} & 475 & 154 & 629 & \multirow{4}{*}{0,058} \\
\hline & & $75,5 \%$ & $24,5 \%$ & $100 \%$ & \\
\hline & \multirow{2}{*}{ egyéb } & 300 & 127 & 427 & \\
\hline & & $70,3 \%$ & $29,7 \%$ & $100 \%$ & \\
\hline \multirow{4}{*}{$\begin{array}{l}\text { Több, mint } \\
\text { három } \\
\text { eszközzel } \\
\text { rendelkezik }\end{array}$} & \multirow{2}{*}{ igen } & 189 & 67 & 256 & \multirow{4}{*}{0,855} \\
\hline & & $73,8 \%$ & $26,2 \%$ & $100 \%$ & \\
\hline & \multirow{2}{*}{ nem } & 586 & 214 & 800 & \\
\hline & & $73,3 \%$ & $26,8 \%$ & $100 \%$ & \\
\hline
\end{tabular}

Forrás: A szerzők saját szerkesztése. 
7. számú táblázat: Válaszadók jelszómódositási gyakorisága

\begin{tabular}{|c|c|c|c|c|c|}
\hline \multirow[t]{2}{*}{ Változók } & \multirow[t]{2}{*}{ Kategóriák } & \multicolumn{2}{|c|}{$\begin{array}{l}\text { Milyen gyakran módosítja } \\
\text { az online felületek eléréséhez } \\
\text { szükséges jelszavait? }\end{array}$} & \multirow[t]{2}{*}{$\begin{array}{l}\text { Összes } \\
\text { válasz }\end{array}$} & \multirow[t]{2}{*}{ P-érték } \\
\hline & & Nem rendszeresen & Rendszeresen & & \\
\hline \multirow{4}{*}{ Nem } & \multirow{2}{*}{ férfi } & 577 & 275 & 852 & \multirow{4}{*}{0,282} \\
\hline & & $67,7 \%$ & $32,3 \%$ & $100 \%$ & \\
\hline & \multirow{2}{*}{ nő } & 172 & 69 & 241 & \\
\hline & & $71,4 \%$ & $28,6 \%$ & $100 \%$ & \\
\hline \multirow{4}{*}{$\begin{array}{l}\text { Legmagasabb } \\
\text { iskolai } \\
\text { végzettség }\end{array}$} & \multirow{2}{*}{$\begin{array}{l}\text { általános vagy } \\
\text { középiskola }\end{array}$} & 333 & 123 & 456 & \multirow{4}{*}{$\mathbf{0 , 0 0 7}$} \\
\hline & & $73,0 \%$ & $27,0 \%$ & $100 \%$ & \\
\hline & \multirow{2}{*}{$\begin{array}{l}\text { föiskola vagy } \\
\text { egyetem }\end{array}$} & 424 & 224 & 648 & \\
\hline & & $65,4 \%$ & $34,6 \%$ & $100 \%$ & \\
\hline \multirow{4}{*}{ Generáció } & \multirow{2}{*}{$\begin{array}{l}\text { X vagy } \\
\text { Baby-boom }\end{array}$} & 459 & 228 & 687 & \multirow{4}{*}{0,112} \\
\hline & & $66,8 \%$ & $33,2 \%$ & $100 \%$ & \\
\hline & \multirow{2}{*}{$\begin{array}{l}\text { Y vagy } \\
\text { Z generáció }\end{array}$} & 297 & 119 & 416 & \\
\hline & & $71,4 \%$ & $28,6 \%$ & $100 \%$ & \\
\hline \multirow{4}{*}{$\begin{array}{l}\text { Napi szinten } \\
\text { több, mint hat } \\
\text { órát használja } \\
\text { az eszközeit }\end{array}$} & \multirow{2}{*}{ 0-6 óra } & 346 & 143 & 489 & \multirow{4}{*}{0,163} \\
\hline & & $70,8 \%$ & $29,2 \%$ & $100 \%$ & \\
\hline & \multirow{2}{*}{$6 \leq$ óra } & 411 & 204 & 615 & \\
\hline & & $66,8 \%$ & $33,2 \%$ & $100 \%$ & \\
\hline \multirow{4}{*}{ Lakóhely } & \multirow{2}{*}{$\begin{array}{l}\text { Budapest vagy } \\
\text { megyei jogú város }\end{array}$} & 440 & 218 & 658 & \multirow{4}{*}{0,140} \\
\hline & & $66,9 \%$ & $33,1 \%$ & $100,0 \%$ & \\
\hline & \multirow{2}{*}{ egyéb } & 317 & 129 & 446 & \\
\hline & & $71,1 \%$ & $28,9 \%$ & $100,0 \%$ & \\
\hline \multirow{4}{*}{$\begin{array}{l}\text { Több, mint } \\
\text { három } \\
\text { eszközzel } \\
\text { rendelkezik }\end{array}$} & \multirow{2}{*}{ igen } & 172 & 94 & 266 & \multirow{4}{*}{0,115} \\
\hline & & $64,7 \%$ & $35,3 \%$ & $100,0 \%$ & \\
\hline & \multirow{2}{*}{ nem } & 585 & 253 & 838 & \\
\hline & & $69,8 \%$ & $30,2 \%$ & $100,0 \%$ & \\
\hline
\end{tabular}

Forrás: A szerzők saját szerkesztése. 
8. számú táblázat: Válaszadók ismerete a zsarolóvírust illetően

\begin{tabular}{|c|c|c|c|c|c|}
\hline \multirow[b]{2}{*}{ Változók } & \multirow[b]{2}{*}{ Kategóriák } & \multicolumn{2}{|c|}{$\begin{array}{c}\text { Zsarolóvírusnak nevezzük azokat } \\
\text { a rosszindulatú programokat, } \\
\text { amelyek... }\end{array}$} & \multirow{2}{*}{$\begin{array}{l}\text { Összes } \\
\text { válasz }\end{array}$} & \multirow[b]{2}{*}{ P-érték } \\
\hline & & $\begin{array}{l}\text { titkosítják a } \\
\text { számítógépes } \\
\text { eszközön tárolt } \\
\text { adatokat }\end{array}$ & $\begin{array}{l}\text { ellopják a } \\
\text { felhasználók } \\
\text { jelszavait / } \\
\text { nem tudja }\end{array}$ & & \\
\hline \multirow{4}{*}{ Nem } & \multirow{2}{*}{ férfi } & 764 & 88 & 852 & \multirow{4}{*}{$<0,001$} \\
\hline & & $89,7 \%$ & $10,3 \%$ & $100 \%$ & \\
\hline & \multirow{2}{*}{ nő } & 144 & 97 & 241 & \\
\hline & & $59,8 \%$ & $40,2 \%$ & $100 \%$ & \\
\hline \multirow{4}{*}{$\begin{array}{l}\text { Legmagasabb } \\
\text { iskolai } \\
\text { végzettség }\end{array}$} & \multirow{2}{*}{$\begin{array}{l}\text { általános vagy } \\
\text { középiskola }\end{array}$} & 359 & 97 & 456 & \multirow{4}{*}{0,002} \\
\hline & & $78,7 \%$ & $21,3 \%$ & $100 \%$ & \\
\hline & \multirow{2}{*}{$\begin{array}{l}\text { föiskola vagy } \\
\text { egyetem }\end{array}$} & 557 & 91 & 648 & \\
\hline & & $86,0 \%$ & $14,0 \%$ & $100 \%$ & \\
\hline \multirow{4}{*}{ Generáció } & \multirow{2}{*}{$\begin{array}{l}\text { X vagy } \\
\text { Baby-boom }\end{array}$} & 556 & 131 & 687 & \multirow{4}{*}{0,022} \\
\hline & & $80,9 \%$ & $19,1 \%$ & $100 \%$ & \\
\hline & \multirow{2}{*}{$\begin{array}{l}\text { Y vagy } \\
Z \text { generáció }\end{array}$} & 359 & 57 & 416 & \\
\hline & & $86,3 \%$ & $13,7 \%$ & $100 \%$ & \\
\hline \multirow{4}{*}{$\begin{array}{l}\text { Napi szinten } \\
\text { több, mint hat } \\
\text { órát használja } \\
\text { az eszközeit }\end{array}$} & \multirow{2}{*}{ 0-6 óra } & 363 & 126 & 489 & \multirow{4}{*}{$<0,001$} \\
\hline & & $74,2 \%$ & $25,8 \%$ & $100 \%$ & \\
\hline & \multirow{2}{*}{$6 \leq$ óra } & 553 & 62 & 615 & \\
\hline & & $89,9 \%$ & $10,1 \%$ & $100 \%$ & \\
\hline \multirow{4}{*}{ Lakóhely } & \multirow{2}{*}{$\begin{array}{l}\text { Budapest vagy } \\
\text { megyei jogú város }\end{array}$} & 562 & 96 & 658 & \multirow{4}{*}{0,009} \\
\hline & & $85,4 \%$ & $14,6 \%$ & $100 \%$ & \\
\hline & \multirow{2}{*}{ egyéb } & 354 & 92 & 446 & \\
\hline & & $79,4 \%$ & $20,6 \%$ & $100 \%$ & \\
\hline \multirow{4}{*}{$\begin{array}{l}\text { Több, mint } \\
\text { három } \\
\text { eszközzel } \\
\text { rendelkezik }\end{array}$} & \multirow{2}{*}{ igen } & 233 & 33 & 266 & \multirow{4}{*}{0,021} \\
\hline & & $87,6 \%$ & $12,4 \%$ & $100 \%$ & \\
\hline & \multirow{2}{*}{ nem } & 683 & 155 & 838 & \\
\hline & & $81,5 \%$ & $18,5 \%$ & $100 \%$ & \\
\hline
\end{tabular}

Forrás: A szerzők saját szerkesztése.

Egyedül a legmagasabb iskolai végzettség áll azzal kapcsolatban, hogy milyen gyakran módosítanak jelszót online felületek esetén a felhasználók (7. számú táblázat). A felsőfokú végzettség esetén gyakrabban válaszolták azt, hogy rendszeresen változtatnak jelszót $(\mathrm{P}=0,007)$, viszont ez az arány náluk is mindössze 34,6\%. A kitöltők 83,0\%-a válaszolta helyesen, hogy mik a zsarolóvírusok (8. számú táblázat). Ez szignifikánsan kedvezőbb volt a férfiak ( $\mathrm{P}<0,001)$, föiskolai 
vagy egyetemi diplomával rendelkezők $(\mathrm{P}<0,002)$, fiatalabb generációk $(\mathrm{P}=0,022)$ esetén, továbbá azoknál is, akik legalább napi hat órát használják az elektronikus eszközeiket $(\mathrm{P}<0,001)$, valamint, akik Budapesten vagy más megye jogú városban élnek ( $\mathrm{P}=0,009)$, és akiknek több mint három fajta eszközük van ( $\mathrm{P}=0,021)$. A felsőfokú végzettséggel rendelkezőkre $(\mathrm{P}=0,047)$ és az idősebb generációkra $(\mathrm{P}=0,036)$ inkább jellemző, hogy elfogadhatatlannak tartanák azt, ha valamilyen őket érintő felhasználói adatot kiszivárogtatnának (9. számú táblázat).

9. számú táblázat: Válaszadók bizalomvesztése adatszivárgás esetén

\begin{tabular}{|c|c|c|c|c|c|}
\hline \multirow{2}{*}{ Változók } & \multirow{2}{*}{ Kategóriák } & \multicolumn{2}{|c|}{$\begin{array}{l}\text { Milyen mértékü bizalomvesztést ered- } \\
\text { ményezne Önnél, ha kiderülne, hogy } \\
\text { egyik szolgáltatója felhasználói adato- } \\
\text { kat szivárogtat ki? }\end{array}$} & \multirow{2}{*}{$\begin{array}{l}\text { Összes } \\
\text { válasz }\end{array}$} & \multirow{2}{*}{ P-érték } \\
\hline & & $\begin{array}{c}\text { Elfogadhatatlannak } \\
\text { tartanám és azonnal } \\
\text { szolgáltatót válta- } \\
\text { nék }\end{array}$ & $\begin{array}{c}\text { Nem okozna } \\
\text { komoly bizalom- } \\
\text { vesztést }\end{array}$ & & \\
\hline \multirow{4}{*}{ Nem } & \multirow{2}{*}{ férfi } & 581 & 203 & 784 & \multirow{4}{*}{0,878} \\
\hline & & $74,1 \%$ & $25,9 \%$ & $100 \%$ & \\
\hline & \multirow{2}{*}{ nő } & 153 & 52 & 205 & \\
\hline & & $74,6 \%$ & $25,4 \%$ & $100 \%$ & \\
\hline \multirow{4}{*}{$\begin{array}{l}\text { Legmagasabb } \\
\text { iskolai } \\
\text { végzettség }\end{array}$} & \multirow{2}{*}{$\begin{array}{l}\text { általános vagy } \\
\text { középiskola }\end{array}$} & 286 & 117 & 403 & \multirow{4}{*}{0,047} \\
\hline & & $71,0 \%$ & $29,0 \%$ & $100 \%$ & \\
\hline & \multirow{2}{*}{$\begin{array}{l}\text { föiskola vagy } \\
\text { egyetem }\end{array}$} & 454 & 139 & 593 & \\
\hline & & $76,6 \%$ & $23,4 \%$ & $100 \%$ & \\
\hline \multirow{4}{*}{ Generáció } & \multirow{2}{*}{$\begin{array}{l}\text { X vagy } \\
\text { Baby-boom }\end{array}$} & 473 & 145 & 618 & \multirow{4}{*}{0,036} \\
\hline & & $76,5 \%$ & $23,5 \%$ & $100 \%$ & \\
\hline & \multirow{2}{*}{$\begin{array}{l}\text { Y vagy } \\
Z \text { generáció }\end{array}$} & 266 & 111 & 377 & \\
\hline & & $70,6 \%$ & $29,4 \%$ & $100 \%$ & \\
\hline \multirow{4}{*}{$\begin{array}{l}\text { Napi szinten } \\
\text { több, mint hat } \\
\text { órát használja } \\
\text { az eszközeit }\end{array}$} & \multirow{2}{*}{ 0-6 óra } & 321 & 119 & 440 & \multirow{4}{*}{0,388} \\
\hline & & $73,0 \%$ & $27,0 \%$ & $100 \%$ & \\
\hline & \multirow{2}{*}{$6 \leq$ óra } & 419 & 137 & 556 & \\
\hline & & $75,4 \%$ & $24,6 \%$ & $100 \%$ & \\
\hline \multirow{4}{*}{ Lakóhely } & \multirow{2}{*}{$\begin{array}{l}\text { Budapest vagy } \\
\text { megyei jogú } \\
\text { város }\end{array}$} & 463 & 148 & 611 & \multirow{4}{*}{0,178} \\
\hline & & $75,8 \%$ & $24,2 \%$ & $100 \%$ & \\
\hline & \multirow{2}{*}{ egyéb } & 277 & 108 & 385 & \\
\hline & & $71,9 \%$ & $28,1 \%$ & $100 \%$ & \\
\hline \multirow{4}{*}{$\begin{array}{l}\text { Több, mint } \\
\text { három } \\
\text { eszközzel } \\
\text { rendelkezik }\end{array}$} & \multirow{2}{*}{ igen } & 182 & 67 & 249 & \multirow{4}{*}{0,615} \\
\hline & & $73,1 \%$ & $26,9 \%$ & $100 \%$ & \\
\hline & \multirow{2}{*}{ nem } & 558 & 189 & 747 & \\
\hline & & $74,7 \%$ & $25,3 \%$ & $100 \%$ & \\
\hline
\end{tabular}

Forrás: A szerzők saját szerkesztése. 
Végezetül a nők $(\mathrm{P}=0,007)$ és a fiatalabb korosztály $(\mathrm{P}=0,012)$ tartja kevésbé valószínűnek azt, hogy közösségi oldalon róluk valamilyen hamis profilt hozzanak létre (10. számú táblázat). Ugyanakkor fontos megemlíteni, hogy ez utóbbi esetén nem egyértelmü, hogy a különbség arra vezethető vissza, hogy valóban kevesebb személyes információt osztanak meg magukról, vagy egyszerüen nem érzik annak a veszélyét, hogy a profilhamisítás velük is megtörténhet.

A válaszlehetőségek kapcsolatának vizsgálata alapján megállapítható, hogy a válaszok között többségében pozitív irányú szignifikáns kapcsolat található (11. számú táblázat). Ez azt jelenti, hogy ha valaki az egyik kérdésre helyes vagy kedvező választ adott, akkor valószínúleg egy másik kérdés esetén is helyes vagy kedvező választ adott. Ugyanakkor fontos megemlíteni, hogy ez nem minden esetben volt észlelhető, és kettő esetben nem szignifikáns fordított kapcsolatot találtunk. A fordított kapcsolat azt jelenti, hogy ha valaki az egyik kérdésre helyes vagy kedvező választ adott, akkor feltehetően a másik kérdésre helytelenül vagy kedvezőtlenül válaszolt. 
10. számú táblázat: Válaszadók véleménye a hamis profil készitésröl

\begin{tabular}{|c|c|c|c|c|c|}
\hline \multirow[b]{2}{*}{ Változók } & \multirow[b]{2}{*}{ Kategóriák } & \multicolumn{2}{|c|}{$\begin{array}{l}\text { Elképzelhetőnek tartja-e, hogy egy } \\
\text { közösségi oldalon valaki az Ôn ne- } \\
\text { vében profilt hozzon létre (lemásolja } \\
\text { a profilját)? }\end{array}$} & \multirow[b]{2}{*}{$\begin{array}{l}\text { Összes } \\
\text { válasz }\end{array}$} & \multirow[b]{2}{*}{ P-érték } \\
\hline & & $\begin{array}{l}\text { Igen, elvégre elég } \\
\text { sok nyilvánosan } \\
\text { elérhető adatot, } \\
\text { képet és informá- } \\
\text { ciót osztok meg } \\
\text { magamról }\end{array}$ & $\begin{array}{c}\text { Nem, mert } \\
\text { minimális ada- } \\
\text { tot osztok meg } \\
\text { magamról, és } \\
\text { azok hozzáféré- } \\
\text { sét is szigorúan } \\
\text { korlátozom }\end{array}$ & & \\
\hline \multirow{4}{*}{ Nem } & \multirow{2}{*}{ férfi } & 235 & 536 & 771 & \multirow{4}{*}{0,007} \\
\hline & & $30,5 \%$ & $69,5 \%$ & $100 \%$ & \\
\hline & \multirow{2}{*}{ nő } & 44 & 165 & 209 & \\
\hline & & $21,1 \%$ & $78,9 \%$ & $100 \%$ & \\
\hline \multirow{4}{*}{$\begin{array}{l}\text { Legmagasabb } \\
\text { iskolai } \\
\text { végzettség }\end{array}$} & \multirow{2}{*}{$\begin{array}{l}\text { általános vagy } \\
\text { középiskola }\end{array}$} & 102 & 301 & 403 & \multirow{4}{*}{0,082} \\
\hline & & $25,3 \%$ & $74,7 \%$ & $100 \%$ & \\
\hline & \multirow{2}{*}{$\begin{array}{l}\text { főiskola vagy } \\
\text { egyetem }\end{array}$} & 178 & 408 & 586 & \\
\hline & & $30,4 \%$ & $69,6 \%$ & $100 \%$ & \\
\hline \multirow{4}{*}{ Generáció } & \multirow{2}{*}{$\begin{array}{l}\text { X vagy } \\
\text { Baby-boom }\end{array}$} & 189 & 417 & 606 & \multirow{4}{*}{0,012} \\
\hline & & $31,2 \%$ & $68,8 \%$ & $100 \%$ & \\
\hline & \multirow{2}{*}{$\begin{array}{l}\text { Y vagy } \\
Z \text { generáció }\end{array}$} & 91 & 291 & 382 & \\
\hline & & $23,8 \%$ & $76,2 \%$ & $100 \%$ & \\
\hline \multirow{4}{*}{$\begin{array}{l}\text { Napi szinten } \\
\text { több, mint hat } \\
\text { órát használja } \\
\text { az eszközeit }\end{array}$} & \multirow{2}{*}{$0-6$ óra } & 125 & 304 & 429 & \multirow{4}{*}{0,614} \\
\hline & & $29,1 \%$ & $70,9 \%$ & $100 \%$ & \\
\hline & \multirow{2}{*}{$6 \leq$ óra } & 155 & 405 & 560 & \\
\hline & & $27,7 \%$ & $72,3 \%$ & $100 \%$ & \\
\hline \multirow{4}{*}{ Lakóhely } & \multirow{2}{*}{$\begin{array}{l}\text { Budapest vagy } \\
\text { megyei jogú város }\end{array}$} & 165 & 433 & 598 & \multirow{4}{*}{0,535} \\
\hline & & $27,6 \%$ & $72,4 \%$ & $100 \%$ & \\
\hline & \multirow{2}{*}{ egyéb } & 115 & 276 & 391 & \\
\hline & & $29,4 \%$ & $70,6 \%$ & $100 \%$ & \\
\hline \multirow{4}{*}{$\begin{array}{l}\text { Több, mint } \\
\text { három } \\
\text { eszközzel } \\
\text { rendelkezik }\end{array}$} & \multirow{2}{*}{ igen } & 71 & 173 & 244 & \multirow{4}{*}{0,753} \\
\hline & & $29,1 \%$ & $70,9 \%$ & $100 \%$ & \\
\hline & \multirow{2}{*}{ nem } & 209 & 536 & 745 & \\
\hline & & $28,1 \%$ & $71,9 \%$ & $100 \%$ & \\
\hline
\end{tabular}

Forrás: A szerzők saját szerkesztése. 
11. számú táblázat: Attitüdök, tudás és szokások mátrixelemzése Khí-négyzet próbával

\begin{tabular}{|c|c|c|c|c|c|c|c|c|}
\hline Kérdés & $\mathrm{K} 2$ & K3 & K4 & K5 & K6 & K7 & K8 & K9 \\
\hline $\begin{array}{l}\text { K1: Ön milyen gyakorisággal } \\
\text { olvas IT-biztonsággal } \\
\text { kapcsolatos híreket? }\end{array}$ & $<0,001$ & 0,008 & 0,459 & $<0,001$ & $<0,001$ & $<0,001$ & 0,010 & 0,005 \\
\hline $\begin{array}{l}\text { K2: Regisztráció során Ön el } \\
\text { szokta olvasni a weboldalak } \\
\text { adatvédelmi szabályzatait? }\end{array}$ & & 0,173 & 0,002 & $<0,001$ & $<0,001$ & 0,144 & 0,099 & $<0,001$ \\
\hline $\begin{array}{l}\text { K3: Ön milyen gyakorisággal } \\
\text { végez biztonsági frissítést } \\
\text { eszközein? }\end{array}$ & & & $<0,001$ & 0,002 & $<0,001$ & 0,009 & $<0,001$ & 0,911 \\
\hline $\begin{array}{l}\text { K4: Használ-e } \\
\text { a számítógépén/laptopján } \\
\text { vírusirtó szoftvert? }\end{array}$ & & & & 0,066 & $<0,001$ & 0,678 & 0,019 & 0,945 \\
\hline $\begin{array}{l}\text { K5: A különböző online } \\
\text { felületeken eltérő jelszavakat } \\
\text { használ, vagy törekszik } \\
\text { a minél kevesebb jelszó } \\
\text { megjegyzésére? }\end{array}$ & & & & & $<0,001$ & $<0,001$ & 0,029 & 0,009 \\
\hline $\begin{array}{l}\text { K6: Milyen gyakran } \\
\text { módosítja az online felületek } \\
\text { eléréséhez szükséges } \\
\text { jelszavait? }\end{array}$ & & & & & & $<\mathbf{0 , 0 0 1}$ & 0,016 & 0,011 \\
\hline $\begin{array}{l}\text { K7: Kérjük, fejezze be } \\
\text { a mondatot! Zsarolóvírusnak } \\
\text { nevezzük azokat } \\
\text { a rosszindulatú programokat, } \\
\text { amelyek... }\end{array}$ & & & & & & & 0,570 & 0,850 \\
\hline $\begin{array}{l}\text { K8: Milyen mértékü } \\
\text { bizalomvesztést } \\
\text { eredményezne Önnél, ha } \\
\text { kiderülne, hogy egyik } \\
\text { szolgáltatója felhasználói } \\
\text { adatokat szivárogtat ki? }\end{array}$ & & & & & & & & 0,549 \\
\hline $\begin{array}{l}\text { K9: Elképzelhetőnek tartja-e, } \\
\text { hogy egy közösségi oldalon } \\
\text { valaki az Ön nevében profilt } \\
\text { hozzon létre? }\end{array}$ & & & & & & & & \\
\hline
\end{tabular}

Megjegyzés: A zöld jelölés pozitív irányú, a sárga jelölés fordított irányú kapcsolatot jelöl.

Forrás: A szerzők saját szerkesztése.

\section{Összegzés}

A mostani kutatás adathalmaza a Nemzeti Kibervédelmi Intézet első olyan felméréséből származik, amely elsősorban az intézetet ismerő populációra irányult, és így feltételezhetően nagy arányban ebből a körből töltötték ki a kérdőívet. Ebből adódóan a 2020-ban, a lakosság körében végzett felmérés csak egy nagyon szük rétegre korlátozódott. A demográfiai adatok alapján megállapítható, 
hogy a vizsgált minta nem tekinthető reprezentatívnak az egész magyarországi lakosságra vonatkozóan, mivel például a férfi és a budapesti kitöltők aránytalanul többen voltak a magyar átlaghoz képest. Bár nagyon nehéz valódi reprezentatív felmérést végezni a lakosság körében, a reprezentativitás mértékét a megfelelö kommunikációs csatornák alkalmazásával lehet javítani (Nyikes, 2017a, 2019). Továbbá azt is figyelembe kell venni, hogy mivel a kérdőív válaszai kategorikusak voltak, nem volt lehetőségünk regresszió elemzés révén a lehetséges zavaró tényezőket figyelembe venni. A reprezentativitás hiánya jelenti a 2020-as vizsgálat egyik legfontosabb korlátját, azonban ezektöl eltekintve az összehasonlító statisztika eredményei nagy mértékben összhangban állnak a hazai és nemzetközi kutatások eredményeivel, ezért is gondoljuk fontosnak a mostani eredmények publikálását és bizonyos összefüggések kiemelését.

Vizsgálatunkban arra a következtetésre jutottunk, hogy a férfiak rendszeresebben olvasnak IT-híreket, gyakrabban használnak eltérő jelszavakat és jobban tisztában vannak a zsarolóvírus fogalmával. A nemzetközi tanulmányok is hasonló megállapítással éltek, miszerint a férfiak tudatosabbak és kedvezőbb szokásokkal rendelkeznek a kiberbiztonság tekintetében (Anwar, He, Ash, Yuan, Li \& Xu, 2017; Cain, Edwards \& Still, 2018; McGill \& Thompson, 2018; Fatokun, Hamid, Norman \& Fatokun, 2019; Zwilling et al., 2020). Ugyanakkor fontos megemlíteni, hogy a magyar felmérésben a nők esetében jellemzőbb volt, hogy van vírusvédelem a gépükön, illetve kevesebb olyan információt osztanak meg magukról, amelyek révén hamis profilt lehetne róluk készíteni. Ez azért lehet érdekes, mert a kisebb kockázatvállalás javítja a helyes kiberbiztonsági szokásokat (Kennison \& Chan-Tin, 2020). Ezt a megállapítást célszerü óvatosan kezelni, mivel a felmérésben a nők kisebb arányban vettek részt az országos megoszláshoz viszonyítva, valamint feltételezhető, hogy inkább azok töltötték ki a kérdőívet, akik érdeklődnek a kiberbiztonság iránt.

Az életkor esetében azt találtuk, hogy az idősebb generációra (Baby-boom vagy $\mathrm{X}$ generációk) igaz, hogy rendszeresebben végeznek biztonsági frissítéseket, gyakrabban használnak vírusirtó programot, valamint kevésbé elnézöek, ha felhasználói adatot szivárogtatnak ki. A hazai kutatások is hasonló következtetésre jutottak (Nyikes, 2017a, 2019), viszont a nemzetközi irodalom nem következetes ezen a téren, mivel néhány tanulmány szerint az idősebbek komolyabban veszik a kiberbiztonságot (Cain et al., 2018; Hadlington, 2018), azonban más vizsgálatban nem találtak szignifikáns összefüggést (McCormac et al., 2016; Gratian, Bandi, Cukier, Dykstra \& Ginther, 2018). Tekintettel arra, hogy a mi vizsgálatunkban is az idősebb generációra volt jellemzőbb, hogy ritkábban olvasnak IT-híreket, kevésbé vannak tisztában a zsarolóvírus fogalmával, és több olyan adatot osztanak meg, amellyel hamis profilt lehet róluk 
készíteni, így nem kizárt, hogy területfüggő, hogy az idősebb generációhoz mikor társul jobb kiberbiztonsági tudás és szokás, és mikor nem. A saját, valamint más hazai és nemzetközi eredmények viszont egyértelmủen megkérdőjelezik azt a sztereotipikus gondolkodást, hogy mivel az idősebbek kevésbé jártasak a modern technológia használatában, a kiberbiztonsági szokásaik is rosszabbak (Cain et al., 2018).

Egy nemzetközi kutatás igazolta, hogy a magasabb iskolai végzettség javítja a kiberbiztonsági szokásokat, viszont ugyanabban a tanulmányban azt találták, hogy a nem és a kor sokkal meghatározóbb tényező volt e tekintetben (Fatokun et al., 2019). A mi vizsgáltunkban arra is fény derült, hogy a felsőfokú végzettséggel rendelkezőknél jellemzőbb volt az IT-hírek olvasása, a vírusirtó program használata, az eltérő jelszavak használata különböző online felületeken, a jelszavak rendszeres megváltoztatása, a zsarolóvírus fogalmának ismerete, valamint kevésbé tartották elfogadhatónak az adatok kiszivárogtatását. A vírusírtókkal kapcsolatos megállapítást egy hazai kutatás eredményei is alátámasztják. Ebben a szerző arra a következtetésre jutott, hogy az iskolai végzettséggel lineárisan nő a vírusirtók használatának valószínúsége (Nyikes, 2017a; Nyikes, 2019).

A különbözö eszközök használatának száma és a lakóhely tekintetében, bár találtunk szignifikáns eltéréseket, de mivel a hazai és nemzetközi irodalomban ezeket nem vizsgálták, nem tudjuk a saját eredményeinket másokéval összevetni. Az eszközhasználat időtartama esetén is csak egy olyan tanulmányt találtunk, amely szerint az internetfüggőség szignifikánsan rontja a kiberbiztonsági szokásokat (Hadlington, 2017). Mivel a függőség nem csak az eszközhasználat idejével áll összefüggésben, így ezen a téren sem tudunk összehasonlítást végezni. Mindenesetre érdemes megemlíteni, hogy a nagyvárosokban élők, a több fajta eszközt használók és az ezeket az eszközöket napi szinten többet használók esetén kedvezőbb válaszokat találtunk.

A módszertani korlátok miatt vizsgálatunkban a válaszokat külön-külön elemeztük, viszont a válaszok közötti szoros kapcsolat világított rá arra, hogy a kiberbiztonsággal kapcsolatos tudás és szokás egy rendkívül összetett kérdés. A nemzetközi vizsgálatok nemcsak ezeket és a demográfiai tényezőket veszik figyelembe, hanem pszichológiai kérdésekkel a kitöltők attitüdjét, személyiségét, a kockázatvállalás mértékét is figyelembe veszik (Herath \& Rao, 2009; Shappie, Dawson \& Debb, 2020).

A felmérés eredményének feldolgozását követően arra a következtetésre jutottunk, hogy további fejlesztésre van szükség a kérdőívek tekintetében. Célcsoport specifikus kérdésekre, esetleg személyiséget felmérö kérdések beépítésére is szükség lehet a mintanagyság megállapítása mellett, különös figyelemmel a minta reprezentatívitására. 
Összegezve, a felmérés kiértékelésekor megállapítást nyert, hogy fontos a lakosság attitüdjének és tudásának folyamatos monitorozása, valamint célszerü a kapott adatokat összehasonlító statisztika segítségével elemezni, mivel a döntéshozók számára releváns információt tudnak nyújtani.

A 2020 októberében Magyarországon végzett nagymintás, elektronikus kérdőívvel végzett lakossági kiberbiztonságra vonatkozó biztonságtudatossági felmérés kapcsán megállapítható, hogy annak eredményei sok tekintetben hasonlóak a hazai és nemzetközi eredményekhez, vagyis számos olyan tényező van (életkori csoport, nem, iskolázottság, lakóhely stb.), amelyek befolyásolják a biztonságtudatosság különböző összetevőit. A felmérés kapcsán fontos kiemelni, hogy a megfelelő statisztikai módszerek alkalmazhatósága érdekében szükséges a felmérési módszertan és a mintavételezés további fejlesztése, a reprezentativitás megteremtése. Az évente rendszeresen végzendő vizsgálatok jól nyomon követhetővé teszik a biztonságtudatosság alakulását, és megfelelő alapot jelentenek olyan célzott intézkedések tervezésére, amely a kibertérben növeli a kiszolgáltatott célcsoportok tudatosságát és ellenállóképességét.

\section{Felhasznált irodalom}

Anwar, M., He, W., Ash, I., Yuan, X. H., Li, L. \& Xu, L. (2017). Gender difference and employees' cybersecurity behaviors. Computers in Human Behavior, 69(1), 437-443. https://doi. org/10.1016/j.chb.2016.12.040

Cain, A. A., Edwards, M. E. \& Still, J. D. (2018). An exploratory study of cyber hygiene behaviors and knowledge. Journal of Information Security and Applications, 42(1), 36-45. https:// doi.org/10.1016/j.jisa.2018.08.002

Fatokun, F. B., Hamid, S., Norman, A. \& Fatokun, J. O. (2019). The Impact of Age, Gender, and Educational level on the Cybersecurity Behaviors of Tertiary Institution Students: An Empirical investigation on Malaysian Universities. Journal of Physics: Conference Series, 1339(1), 012098. https://doi.org/10.1088/1742-6596/1339/1/012098

Gratian, M., Bandi, S., Cukier, M., Dykstra, J. \& Ginther, A. (2018). Correlating human traits and cyber security behavior intentions. Computers \& Security, 73(1), 345-358. https://doi. org/10.1016/j.cose.2017.11.015

Hadlington, L. (2017). Human factors in cybersecurity; examining the link between Internet addiction, impulsivity, attitudes towards cybersecurity, and risky cybersecurity behaviours. Heliyon, 3(7), e00346. https://doi.org/10.1016/j.heliyon.2017.e00346

Hadlington, L. (2018). Employees Attitude towards Cyber Security and Risky Online Behaviours: An Empirical Assessment in the United Kingdom. International Journal of Cyber Criminology, 12(1), 269-281. https://doi.org/10.5281/zenodo.1467909 
Herath, T. \& Rao, H. R. (2009). Protection motivation and deterrence: a framework for security policy compliance in organisations. European Journal of Information Systems, 18(2), 106-125. https://doi.org/10.1057/ejis.2009.6

Herzog, A. R. \& Bachman, J. G. (1981). Effects of Questionnaire Length on Response Quality. The Public Opinion Quarterly, 45(4), 549-559. https://doi.org/10.1086/268687

Kennison, S. M. \& Chan-Tin, E. (2020). Taking Risks with Cybersecurity: Using Knowledge and Personal Characteristics to Predict Self-Reported Cybersecurity Behaviors. Frontiers in Psychology, 11(1), 546546. https://doi.org/10.3389/fpsyg.2020.546546

McCormac, A., Zwaans, T., Parsons, K., Calic, D., Butavicius, M. \& Pattinson, M. (2017). Individual differences and Information Security Awareness. Computers in Human Behavior, 69(1), 151-156. https://doi.org/10.1016/j.chb.2016.11.065

McGill, T. \& Thompson N. (2018). Gender Differences in Information Security Perceptions and Behaviour. Australasian Conference on Information Systems, Sydney.

Nyikes, Z. (2017a). A Közép-Kelet európai generációk digitális kompetencia és biztonságtudatosság vizsgálatának eredményei. Hadmérnök, 12(4), 159-174.

Nyikes, Z. (2017b). A Digitális Kompetencia Értékelési Rendszerének Egyes Kérdései. XXII. Fiatal Müszakiak Tudományos Ülésszaka, Kolozsvár. Müszaki tudományos közlemények 7. 323-326. https://doi.org/10.33895/mtk-2017.07.73

Nyikes, Z. (2019). A Közép-Kelet európai generációk digitális kompetencia és biztonságtudatosság vizsgálatának eredményei. $\mathrm{PhD}$ értekezés. Óbudai Egyetem, Biztonságtudományi Doktori Iskola.

Oroszi, E. D. (2020). Social Engineering a koronavírus tükrében, avagy a rendkívüli helyzetet kihasználó támadási technikák és megelőzésük. Dunakavics, 8(5), 5-20.

Palicz, T., Bencsik, B. \& Szócska, M. (2021). Kiberbiztonság a koronavírus idején a COVID-19 nemzetbiztonsági aspektusai. Scientia et Securitas, 2(1), 78-87. https://doi. org/10.1556/112.2021.00001

Sasse, M. \& Flechais, I. (2005). Usable Security: Why Do We Need It? How Do We Get It? In Cranor, L. F. \& S. Garfinkel (Eds.), Security and Usability (pp. 13-30). O'Reilly Publishing. Shappie, A. T., Dawson, C. A. \& Debb, S. M. (2020). Personality as a predictor of cybersecurity behavior. Psychology of Popular Media, 9(4), 475-480. https://doi.org/10.1037/ppm0000247

Szabó, H. (2021). Kiberbiztonság a koronavírus-járvány idején - a COVID-19 nemzetbiztonsági aspektusai. Rendvédelem, 10(1), 52-70.

Zwilling, M., Klien, G., Lesjak, D., Wiechetek, L., Cetin, F. \& Basim, H. N. (2020). Cyber Security Awareness, Knowledge and Behavior: A Comparative Study. Journal of Computer Information Systems, 1-20. https://doi.org/10.1080/08874417.2020.1712269 


\section{A cikkben található online hivatkozások}

URL1: A hálózati és információs rendszerek biztonságára vonatkozó Stratégia végrehajtásának 2020-2022. évekre vonatkozó intézkedési terve. https://2015-2019.kormany.hu/downlo$\mathrm{ad} / 3 / 6 \mathrm{~d} / \mathrm{b} 1000 /$ Int\%C3\%A9zked\%C3\%A9si\%20terv\%202020-2022.pdf\#!DocumentBrowse URL2: EUSurvey. https://ec.europa.eu/eusurvey/home/welcome

\section{Alkalmazott jogszabályok}

1838/2018. (XII. 28.) Korm. határozat Magyarország hálózati és információs rendszerek biztonságára vonatkozó Stratégiájáról

\section{A cikk APA szabály szerinti hivatkozása}

Palicz T., Bonnyai T., Bencsik B., Pintér L., Hornyik Zs., Joó T., Bor O. \& Dombrádi V. (2022). Biztonságtudatosság a kibertérben - a 2020-as országos lakossági felmérés eredményei. Belügyi Szemle, 70(2), 395-418. https://doi.org/10.38146/BSZ.2022.2.11 